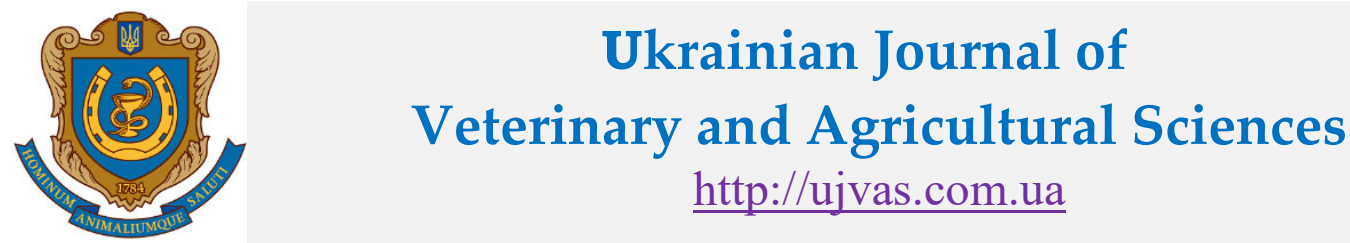

Stepan Gzhytskyi National University of Veterinary Medicine and Biotechnologies Lviv original article $\mid$ UDC 619:614.48 $\mid$ doi: 10.32718/ujvas2-2.09 2

\title{
Determination of acute toxicity parameters of "Zoodizin" disinfectant
}

\author{
O. L. Nechyporenko, A. V. Berezovskyy, H. A. Fotina, R. V. Petrov, T. I. Fotina \\ Sumy National Agrarian University, Gerasim Kondratyev Str., 160, Sumy, 40000, Ukraine
}

Article info
Received 24.09.2019
Received in revised form
28.10 .2019
Accepted 29.10.2019
Correspondence author
Tatiana Fotina
Tel.: +38-095-495-29-33
E-mail: tif_ua@meta.ua
C) 2019 Nechyporenko O. L. et al.
This is an open-access article
distributed under the terms of the
Creative Commons Attribution
License, which permits unrestricted
use, distribution, and reproduction
in any medium, provided the
original author and source are
credited.

credited.

\section{$(\mathrm{cc}) \mathrm{BY}$}

Contents

1. Introduction

2. Materials and methods

3. Results and discussion ...... 42

4. Conclusions ................. 43

References ....................... 43

\begin{abstract}
An important element in ensuring the epizootic well-being of the poultry industry is disinfection. Modern poultry farming requires a large number of effective disinfectants. It is known that the resistance of microorganisms to the effects of disinfectants is based on a genotypic mechanism. The nature of the formation of resistance to disinfectants and antiseptics is different than antibiotics. With regard to disinfectants, resistance is formed more slowly and the proportion of resistant strains in the population of microorganisms may not be high for a long time. This is due to different mechanisms of formation of resistance to antibiotics and disinfectants, in the first case - plasmid mechanism, in the second - chromosomal. However, increasing the resistance to the active substance in disinfectants can be widespread, so it is necessary to periodically rotate disinfectants. The goal of the work - to investigate the parameters of acute toxicity of the disinfectant biocide "Zodizin". The studies were conducted in the laboratory of Veterinary Pharmacy and the Vivarium of Sumy National Agrarian University. The drug "Zodizine" contains: polyhexamethyleneguanidine hydrochloride $-21.0 \%$, alkylldimethylbenzylammonium chloride $-3.0 \%$. For toxicological examination of the disinfectant, healthy white male rats and white female rats weighing $200 \pm 10 \mathrm{~g}$ 1.5 years of age were used. In the study of acute toxicity of animals observed daily, noted the general condition of the animals, features of their behavior. Studies have found that the toxic effect of the disinfectant "Zodizin" clinically manifested almost equally in both males and females. The average lethal dose for the rat female was $1000.0 \pm 35.0 \mathrm{mg} / \mathrm{kg}$ body weight, males $1033.0 \pm 34.3 \mathrm{mg} / \mathrm{kg}$. Therefore, according to the classification of substances by toxicity, the drug by intragastric administration can be attributed to low-toxic substances. Observations on animals revealed that $1-3$ hours after oral administration of the drug in a subtoxic dose in laboratory animals, shortness of breath and inhibition of the central nervous system were noted. Most of them died during the first day. Subsequent observations of the surviving animals indicated that their motor response was suppressed over the next 24-72 hours. Conclusions and prospects for further research: 1. It was found that the average lethal dose of the drug "Zodizin" with oral administration to rats-females was $1000.0 \pm 35.0 \mathrm{mg} / \mathrm{kg}$ body weight, males $-1033.0 \pm$ $34.3 \mathrm{mg} / \mathrm{kg}$. 2. Experimental studies have proved that the disinfectant "Zodizin" according to GOST 12.1.007-76, belongs to the IV class of danger, that is, to the low-dangerous compounds, and according to GOST $12.1 .07-$ to the III class of hazard of substances and can be used for disinfection premises where animals and poultry are kept. Further, the sporocide and corrosion properties of the "Zoodizin" biocide will be studied.
\end{abstract}

Key words: poultry farming, disinfectant, disinfection, "Zoodizin" biocide, acute toxicity.

\section{Citation:}

Nechyporenko, O. L., Berezovskyy, A. V., Fotina, H. A., Petrov, R. V., \& Fotina, T. I. (2019). Determination of acute toxicity parameters of "Zoodizin" disinfectant. Ukrainian Journal of Veterinary and Agricultural Sciences, 2(2), 41-44.

\section{Introduction}

Disinfection is an important link in ensuring the epizootic well-being of the poultry industry (Verbytskyi, 2004; Fotina \& Fotina, 2014). Modern poultry farming requires a large number of effective disinfectants. More than three thousand tons is the annual need for disinfectants for the domestic poultry industry. Form this amount of disinfectants from 161 item names. The highest percentage of this amount $(67.9 \%)$ is the group of alkaline agents. The second largest group $(12.4 \%)$ is formed by aldehydes (mainly Glutaraldehyde,) and quaternary Ammonium compounds (Stehnii et al., 2010). The third group (11.1\%) is acid-containing disinfectants. The rest $(8.6 \%)$ are chlorine-based disinfectants and quaternary ammonium compounds without aldehydes only (Nechyporenko \& Berezovskyi, 2017).
It is known that the resistance of microorganisms to the effects of disinfectants is based on a genotypic mechanism, which has not yet been elucidated (Mariievskyi, 2008). However, the nature of the formation of resistance to disinfectants and antiseptics is different than that of antibiotics. In reference to disinfectants, resistance is formed more slowly and the proportion of resistant strains in the population of microorganisms may not be high for a long time. It depends on various mechanisms of formation of resistance to antibiotics and disinfectants, in the first case it is a plasmid mechanism, in the second it is chromosomal (Champan, 2003). However, increasing the resistance to the active substance in disinfectants can contribute to the frequency of distribution, so it is necessary to rotate the disinfectants periodically (Stehnii et al., 2010; Instruktsiia z provedennia sanitarnoi obrobky, 2016). 
Therefore, a long-range research plan is the creation of new domestic disinfectants to which the resistance of microorganisms has not yet formed.

The purpose and objectives of the study. To investigate the parameters of acute toxicity of the disinfectant biocide "Zoodizin". To achieve this goal it was necessary to solve the following problems:

1. To establish on white rats parameters of acute toxicity of the biocide "Zoodizin".

2. To draw an inference from using the biocide in the presence of animals and birds.

\section{Materials and methods}

The studies were conducted in the laboratory of Veterinary Pharmacy and the Vivarium of Sumy National Agrarian University. Pharmaceutical form of "Zoodizin" is composed of Polyhexamethylene guanidine - $21.0 \%$, alkylldimethylbenzylammonium chloride - 3.0\%. The study of the toxic properties of the experimental drug "Zoodizin" was carried out according to the "Methodical instructions for determining the toxic properties of drugs used in veterinary and animal husbandry". For toxicological examination of the disinfectant, healthy white male rats and white female rats weighing $200 \pm 10 \mathrm{~g} 1.5$ years of age were used. Maintained laboratory animals in accordance with the current "Sanitary rules for the construction, equipment and maintenance of experimental biological clinics" on a unified diet. Animals were monitored daily for acute toxicity studies. Determined the general condition of the animals, the features of their behaviour, the tone of the skeletal muscles, the response to tactile, pain, sound and light stimuli, the frequency and depth of respiratory movements, heart rate, hair and skin, mucosal colour, pupil size, position tail, amount and consistency of faeces, purity of urination and staining of urine, consumption of feed and water, determination of body weight. The effect of the biocide "Zoodizin" was evaluated by the main physiological indicators: behavioural reactions - motor activity (speed and force of movement, the ability of the animal to stay in one pose), excitability (in the stupor or alertness of the animal), manifestation of unusual sharp and rapid movements, reactivity (by the reaction of the animal to changing the environment: moving to the open table), aggressiveness (by behaviour between males, reactions to touch when performing standard manipulations); neuromuscular: tremors, convulsions, ataxia, reflexes, posture of the body in a normal posture and after giving it inconvenient, tail Stroub reaction (by the degree of tail lift), reaction to the touch (by the intensity of depriving the animal of light stroking of the body from three sides), grip strength (by the grip force of the animal on the lattice); vegetative: pupil size (by area, occupied pupil), salivation (by humidity and irrigation of saliva of the oral cavity), body temperature, skin colour (by the intensity of the colour of the plantar surface of the fore paws, ears), rate of breathing (Kotsiumbas et al., 2013; Gutyj et al., 2016; Todoriuk et al., 2018).

\section{Results and discussion}

Studies have found that the toxic effect of the disinfectant "Zoodizin" clinically manifested almost equally in both males and females (Tables 1,2).

The average lethal dose of the agent for female rats was $1000.0 \pm 35.0 \mathrm{mg} / \mathrm{kg}$ body mass, for males $-1033.0 \pm$ $34.3 \mathrm{mg} / \mathrm{kg}$. Therefore, according to the classification of substances by toxicity, the investigated drug can be attributed to low-toxic substances (class IV).

Table 1

Determination of the average lethal dose deposition of "Zoodizin" in female rats

\begin{tabular}{|c|c|c|c|c|c|}
\hline \multirow{2}{*}{ Indicators } & \multicolumn{5}{|c|}{ Dose of the drug, $\mathrm{mg} / \mathrm{kg}$ (per os) } \\
\hline & 800 & 900 & 1000 & 1100 & 1200 \\
\hline $\begin{array}{l}\text { Total number of animals } \\
\text { among them: }\end{array}$ & 6 & 6 & 6 & 6 & 6 \\
\hline surviving animals & 6 & 4 & 4 & 1 & 0 \\
\hline dead animals $(\%)$ & 0 & $2(33.3)$ & $2(33.3)$ & $5(83.3)$ & $6(100)$ \\
\hline Z & & 1.0 & 2.0 & 3.5 & 5.5 \\
\hline $\mathrm{D}$ & 100 & 100 & 100 & 100 & 100 \\
\hline $\mathrm{DZ}$ & & 100 & 200 & 350 & 550 \\
\hline
\end{tabular}

Table 2

Determination of the average lethal dose of the drug "Zoodizin" in male rats

\begin{tabular}{lccccc}
\hline \multicolumn{1}{c}{ Indicators } & \multicolumn{3}{c}{ Dose, $\mathrm{mg} / \mathrm{kg}$} \\
\cline { 2 - 5 } & 800 & 900 & 1000 & 1100 \\
\hline Total number of animals, heads & 6 & 6 & 6 & 6 & \\
Out of these: & & & 4 & 200 \\
survived, heads & 6 & 5 & $2(33.3)$ & $4(66.7)$ & $6(100)$ \\
have died, heads (\%) & 0 & $1(16.6)$ & 3.0 & 0 & 5.5 \\
Z & 0.5 & 1.5 & 100 & 100 & 100 \\
D & 100 & 100 & 150 & 300 & 500 \\
DZ & & 50 & & & 6 \\
\hline
\end{tabular}


It has been established by the Animal monitoring, that in 1-3 hours after oral administration of the drug in a subtoxic dose in laboratory animals noted shortness of breath and inhibition of the central nervous system. Most of them died during the first day. Subsequent observations of the surviving animals indicated that their motor response was suppressed over the next 24-72 hours. In addition, experimental rats showed a marked decrease in motor activity, excitability, reactivity and aggressiveness, movement disor- ders, reduced response to touch and pain irritation, grip strength, as well as a decrease in respiratory rate.

After the pathoanatomical dissection of the dead animals, the following was established: the walls of the abdominal cavity were smooth, shiny, slightly moistened; the surface of the liver was smooth and shiny, slightly hyperemic; the parietal and visceral pleura were also smooth, shiny, effusions and adhesions not detected; pulmonary tissue pink, hyperemic, without thickening, elastic; round heart bag and heart unchanged (Table 3).

Table 3

Effect of subtoxic dose of disinfectant "Zoodizin" at oral administration on the general functional parameters of experimental rats

\begin{tabular}{|c|c|c|c|}
\hline \multirow{2}{*}{ Indicators } & \multicolumn{3}{|c|}{ Observation time, $\mathrm{h}$. } \\
\hline & 6 & 24 & 72 \\
\hline \multicolumn{4}{|l|}{ Behavioral reactions: } \\
\hline motor activity & -2 & -1 & -1 \\
\hline excitement & -3 & -2 & -1 \\
\hline reactivity & -3 & -2 & -1 \\
\hline aggression & -2 & -1 & -1 \\
\hline \multicolumn{4}{|l|}{ Neuromuscular reactions: } \\
\hline tremor & 0 & 0 & 0 \\
\hline seizures during the course & -1 & 0 & 0 \\
\hline reaction to painful irritation & -1 & -1 & 0 \\
\hline grip strength & -2 & -1 & 0 \\
\hline \multicolumn{4}{|l|}{ Vegetative reactions: } \\
\hline the size of the eye pupil & unchanged & & \\
\hline respiratory rate & slowed down & & \\
\hline condition of woolen cover & slight smoking & & \\
\hline the color of the mucous membranes & slight blueness & & \\
\hline the number of fecal masses & a slight increase & & \\
\hline the consistency of fecal masses & semi-rare & & \\
\hline frequency of urination & unchanged & & \\
\hline the color of the urine & unchanged & & \\
\hline heart rate & unchanged & & \\
\hline
\end{tabular}

However, there was an enlargement of the coronary vessels, venous sinuses and blood overflow; cerebral vessels are dilated, which is characteristic of the hypoxic condition.

Given that the drug was injected into the stomach with a probe, particular attention was paid to the possibility of macroscopic changes of the organs.

As a result, mechanical stretching of the walls of the stomach and the adjacent portion of the small intestine was noted. The large intestine was without organoleptic changes. The contents of the stomach and small intestine was a foamy muddy fluid. The mucous membrane of this gut fragment had a matte velvety appearance, the folding normally expressed. Subsequent observations of the surviving animals within 2 weeks revealed that they had signs of intoxication (crowding, general depression, muscle tremor). However, at use of the drug in a subtoxic dose, such symptoms of laboratory animal poisoning disappeared within 48-72 hours.

\section{Conclusions}

1. It was found that the average lethal dose of the drug "Zoodizin" at oral administration to rats-females was $1000.0 \pm 35.0 \mathrm{mg} / \mathrm{kg}$ body weight, males $-1033.0 \pm$ $34.3 \mathrm{mg} / \mathrm{kg}$.

2. Experimental studies have proved that the disin- fectant "Zoodizin" according to GOST 12.1.007-76, belongs to the IV class of danger, that is low-dangerous compounds, and according to GOST 12.1.07 - to the III class of hazard of substances and can be used for disinfection premises where animals and poultry are kept.

\section{Conflict of interest}

The authors declared that there is no conflict of interest.

\section{References}

Champan, J. S. (2003). Biocide resistant mechanisms. Intern. Biodetecterioration and Biodegradation, 51(2), 133-138. doi: 10.1016/S0964-8305(02)00097-5.

Fotina, T. I., \& Fotina, H. A. (2014). Mikroflora ptashnykiv. Nashe ptakhivnytstvo, 6(36), 84-88 (in Ukrainian).

Gutyj, B., Paska, M., Levkivska, N., Pelenyo, R., Nazaruk, N., \& Guta, Z. (2016). Study of acute and chronic toxicity of 'injectable mevesel' investigational drug. Biological Bulletin of Bogdan Chmelnitskiy Melitopol State Pedagogical University, 6(2), 174-180. doi: 10.15421/201649.

Instruktsiia $\mathrm{z}$ provedennia sanitarnoi obrobky - dezinfektsii, dezinsektsii ta deratyzatsii obiektiv ptakhivnytstva (2016). Ministerstvo ahrarnoi polityky ta prodovolstva Ukrainy vid 13.04.2016 r. N 156. Rezhym dostupu: http://search.ligazakon.ua/1_doc2.nsf/link1/RE14080.html (in Ukrainian). 
Kotsiumbas, I. Ia., Bisiuk, I. Yu., Horzheiev, V. M., \& Malyk, O. H. (2013). Klinichni doslidzhennia veterynarnykh preparativ ta kormovykh dobavok. L.: TOV Vydavnychyi dim "SAM" (in Ukrainian).

Mariievskyi, V. F. (2008). Vyvchennia protsesiv formuvannia stiikosti mikroorhanizmiv do dezinfektsiinykh zasobiv $\mathrm{z}$ riznykh hrup khimichnykh spoluk. Profilaktychna medytsyna, 2, 13-17 (in Ukrainian).

Nechyporenko, O. L., \& Berezovskyi, A. V. (2017). Suchasnyi rynok dezinfektantiv dlia promyslovoho ptakhivnytstva. Piatnadtsiatyi Mizhnarodnyi konhres spetsialistiv veterynarnoi medytsyny: materialy konhresu. Kyiv, 9-60 (in Ukrainian).
Stehnii, B. T., Kutsan, O. T., Herilovych, A. P., Holovko, A. M., Rublenko, M. V., \& Bisiuk, I. Yu. (2010). Biobezpeka i biozakhyst : svitovyi dosvid, problemy v Ukraini ta shliakhy yikh vyrishennia. Veterynarna medytsyna, 94, 5-12. Rezhym dostupu: http://nbuv.gov.ua/UJRN/vetmed_2010_94_3 (in Ukrainian).

Todoriuk, V. B., Hunchak, V. M., Gutyj, B. V., Gufriy, D. F., Hariv, I. I., Khomyk, R. I., \& Vasiv, R. O. (2018). Preclinical research of the experimental preparation "Ferosel T". Ukrainian Journal of Veterinary and Agricultural Sciences, 1(1), 3-9. doi: 10.32718/ujvas1-1.01.

Verbytskyi, P. I. (2004). Dovidnyk likaria veterynarnoi medytsyny. $\mathrm{K}$.: Urozhai (in Ukrainian). 